\title{
End-to-side neurorrhaphy with and without perineurium
}

\author{
Faculdade de Medicina, Universidade Estadual Paulista/UNESP, São Paulo, Brasil
}

\begin{abstract}
Objective: We compared end-to-side neurorraphy with and without the perineural sheath. Method: Twenty rats were used. The peroneal nerve was sectioned and the distal end was sutured to the lateral face of the tibial nerve. We removed the perineural sheath only on the right side, but not on the left side. The proximal end of the peroneal nerve was curved back approximately at a $100^{\circ}$ angle and implanted into the adductor muscle. Six months later, the 14 surviving animals were submitted to electrophysiological tests, sacrificed, and the nerves and muscles were taken for histological exams. Results: On the right side, the muscles that had positive response needed an average of $258.89 \mathrm{mV}( \pm 92.31)$ of electric stimulus and on the left side $298.34 \mathrm{mV}( \pm 139.32)$. The average weight of the tibial cranial muscles of the right side was $0.47 \mathrm{~g}(0.18)$ and for the left side $0.45 \mathrm{~g}(0.15)$. The distal end of the peroneal nerve showed averages of $310.29( \pm 191.34)$ nerve fibers on the right side and $287.71( \pm 183.60)$ on the left side. The tibial nerve above the neurorraphy showed averages of $939.46( \pm 223.51)$ nerve fibers on the right side and $959.46( \pm 327.48)$ on the left side. The tibial nerve below the neurorraphy showed averages of $935.17( \pm 298.65)$ nerve fibers on the right side and $755.31( \pm 323.26)$ on the left side. The average areas of the right tibial cranial muscles were $0.0162 \mathrm{~m}^{2}( \pm 0.008)$, after 230 magnification, and $0.0152 \mathrm{~m}^{2}(0.0064)$ for the left tibial cranial muscles. The histological features of the tibial cranial muscles, taking normal as $100 \%$, were $78.21( \pm 20.75)$ on the right side and 82.14 ( \pm 15.89$)$ on the left side. The statistical analysis (Student's t test) did not reveal any difference $(p>0.05)$ among right and left sides for all variables. Conclusion: The authors concluded that the two neurorraphies (with and without perineurium) did not show any difference regarding morphological and electrophysiological features studied.
\end{abstract}

Uniterms: End-to-side neurorrhaphy. Microsurgery. Rats.

$\mathrm{R}$ eports on end-to-side neurorrhaphy are found in publications since the beginning of this century. The first report was by Ballance ${ }^{1}$ (1895) on the treatment of facial palsy by suturing the distal end of the sectioned facial nerve laterally to the accessory spinal nerve. Other authors reported the use of this technique in several clinical cases, with some variations. ${ }^{2}$

Kennedy $(1899)^{1}$ and Sherren postulated that an incision in the donor nerve was essential to promote an end-to-end like contact among the two nerves, leaving untouched only the epineurium on the side opposite to the neurorrhaphy.

\author{
Address for correspondence: \\ Fausto Viterbo \\ Rua Magnólia, 265 \\ Botucatu/SP - Brasil - CEP 18607-670
}

Krivolutskaia et al. $^{3}$ recently reported end-to-side neurorrhaphies with scarification or incision in the donor nerve.

When working on our Doctorate dissertation, ${ }^{4}$ we saw for the first time that end-to-side neurorrhaphy was effective without either incision in the donor nerve or removal of its epineurium and perineurium. This finding substantially changed the concepts on the epineurium and perineurium barrier, which opened new possibilities for peripheral nerve surgery. Furthermore, this new finding made the novel neurorrhaphy easier and safer to be used in several clinical cases. Recently, Lundborg $^{5}$ has reported results similar to ours.

Our objective was to compare, in the same animal, end-to-side neurorrhaphy without epineurium removal with end-to-side neurorrhaphy with epineurium and perineurium removal, in an attempt to establish whether 
it is necessary to remove them during the surgical procedure or not.

\section{METHODS}

Twenty male Wistar rats, weighing $153.93 \pm 18.63 \mathrm{~g}$ were used. Each animal had its peroneal nerve sectioned. The distal end was then sutured to the side of the tibial nerve. On the right side, a small window was made in the epineurium and perineurium. On the left side, the donor nerve were left intact (no window) (Fig. 1). The proximal end of the peroneal nerve was curved back approximately at a 100-degree angle and implanted into the abductor muscle.

The animals were given standard rat chow and water ad libitum for about 6 months. At the end of this period, the 14 surviving animals were submitted to electrophysiological tests and sacrificed, having their nerves and muscles of interest removed.

\section{Electrophysiological Study}

The animals were anesthetized and the nerves involved were dissected under the surgical microscope. On both sides, the tibial nerve and the cutaneous caudal nerve of the sura were distally sectioned, approximately 1 $\mathrm{cm}$ below the neurorrhaphy (Fig. 2).

A bipolar stimulating electrode was placed in the sciatic nerve trunk. Two needle electrodes were inserted into the tibial cranial muscles for the detection of electric impulses, which were observed on an oscilloscope screen ${ }^{\mathrm{a}}$.

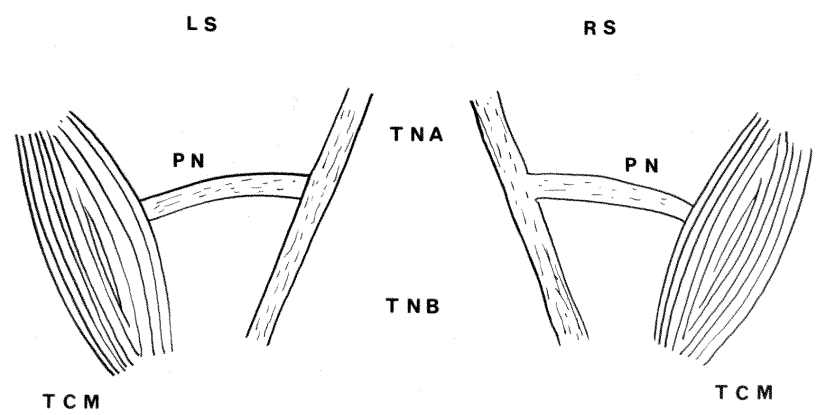

Figure 1 - Illustrations of the various nerves and muscles studied. LS: left side (with perineurium). RS: right side (without perineurium). TNA: segment of the tibial nerve above the neurorraphy. TNB: segment of the tibial nerve below the neurorraphy. PN: segment of the peroneal nerve distal to the neurorraphy. TCM: tibial cranial muscle.
The electrical stimulus was supplied by an LHM-1102 neurostimulator ${ }^{\mathrm{b}}$, with $1 \mathrm{~ms}$ duration, at 30 Hertz frequency and in repeated mode.

The stimulus intensity was progressively increased from 0 to 1 volt.

The muscle response was observed on the oscilloscope screen. Then, the distal end of the peroneal nerve was sectioned approximately $1.5 \mathrm{~cm}$ distal to the neurorrhaphy (Fig. 2), and the electrical stimulation was repeated to observe the disappearance of the muscle response.

After these procedures, the animals were sacrificed with high dose intraperitoneal sodium pentobarbital $\left(\right.$ Nembutal $\left.^{\circledR}\right)$.

\section{Histology}

The following nerve segments were removed bilaterally: the proximal end of the peroneal nerve, the tibial nerve above the neurorrhaphy, the tibial nerve below the neurorrhaphy, the distal end of the peroneal nerve and the segment of the neurorrhaphy.

\section{Nerve Fiber Counting}

The nerves were fixed in $10 \%$ formalin, embedded in paraffin and sectioned. Most sections were carried out transversely, except those at the sites of the end-to-side neurorrhaphies and those at the proximal end of the peroneal nerve which were made longitudinally. The sections were stained using Regand's hematoxylin method. ${ }^{6}$

The tibial cranial muscles were also bilaterally removed and then weighed. Cylinders of approximately 1 $\mathrm{cm}$ in length and $4 \mathrm{~mm}$ in diameter were cut from each muscle, in the middle third of their deepest portion, which were then frozen. Later, sections were made transversely to the largest axis of the fibers, and slides were stained using the hematoxylin-eosin method.

\section{Muscle Histology}

The histological pattern of the muscle fibers was assessed by a blinded collaborator. Histological specimens were given values from 0 to 100 as compared with the normal muscle fibers, taken as $100 \%$.

a. Hewlett-Packard 132A Dual Beam, DC-500 KC Oscilloscope b. LHM-110 Electronic (Electrophysiological) Stimulator(IBBMA/UNESP) 


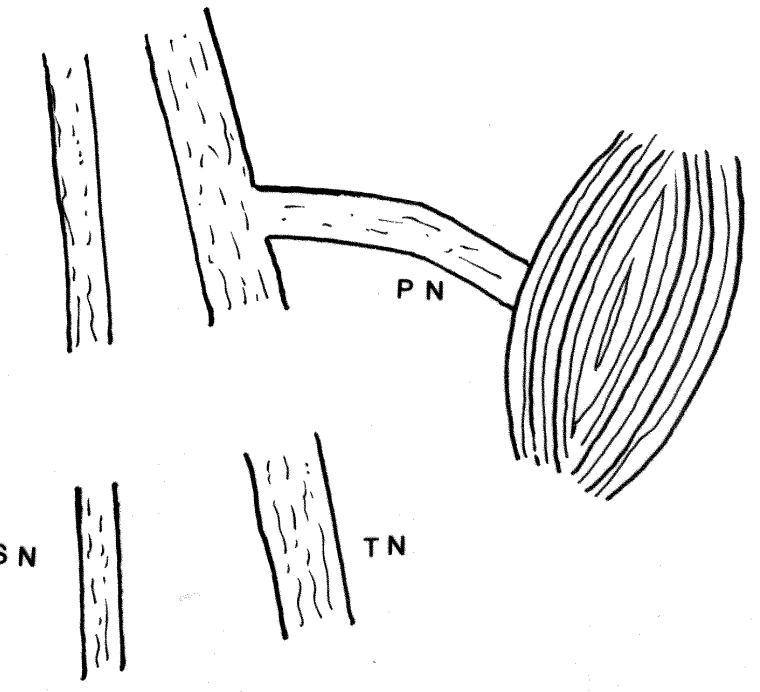

Figure 2 - For the electrophysiological study, the tibial nerve and the cutaneous caudal nerve of the sura were distally sectioned, approximately $1 \mathrm{~cm}$ below the neurorrhaphy. TN: tibial nerve. PN: peroneal nerve. SN: cutaneous caudal nerve of the sura.

\section{Area of the Muscle Fibers}

The transversely-sectioned muscle fibers were photographed with a photomicroscope. The fibers in the photographs, with a final $230 \mathrm{X}$ enlargement, had their areas determined by planimetry. All the fibers that could be entirely seen in the photograph were measured, and the results were expressed in $\mathrm{m}^{2}$ (square meters).

All the transversely sectioned nerves had their nerve fibers counted.

\section{Statistical Analysis}

Comparison between the means for the two sides, for each one of the variables, was made by the Student's $t$ test for paired samples.?

In the comparisons of TNARS (segment of the tibial nerve above the neurorraphy, right side) $x$ TNALS (segment of the tibial nerve above the neurorraphy, left side) and TNBRS (segment of the tibial nerve below the neurorraphy, right side) x TNBLS (segment of the tibial nerve below the neurorraphy, left side), 2 and 3 observations, respectively, were not taken into account due to the absence of the corresponding observation pair.

Thus, the other comparisons were made taking into account 14 observations pairs, while in the two mentioned, 12 and 11 pairs were used.

All of the conclusions were described at $5 \%$ level of significance.

\section{RESULTS}

Nerve Histology. Longitudinal sections at the neurorrhaphy site suggested that the epineurium and perineurium had disappeared and lateral sprouting had occurred (Fig.3). Transversal sections of the peroneal nerve distal to the neurorraphy showed many regenerated nerve fibers.


Figure 3 - Longitudinal sections of the site of the neurorraphy between the end of the peroneal nerve and the side of the tibial nerve. Left: with epineurium. Right: without epineurium. Regaud Haematoxylin, 90 X. 
Nerve Fiber Countings. Data on the different segments studied are shown in Table 1. The distal end of the peroneal nerve showed averages of 310.29 (191.34) nerve fibers on the right side and 287.71 (183.60) on the left side (Fig. 6). The tibial nerve above the neurorrhaphy presented averages of 939.46 (223.51) nerve fibers on the right side and 959.46 (327.48) on the left side. The tibial nerve below the neurorrhaphy exhibited averages of 935.17 (298.65) nerve fibers on the right side and 755.31 (323.26) on the left side.

Muscle Weight. The average weight of the tibial cranial muscles was $0.47 \mathrm{~g}(0.18)$ on the right side and $0.45 \mathrm{~g}(0.15)$ on the left side (Fig. 5).

Muscle Histology. The histological features of the tibial cranial muscles were 78.21 (20.75) on the right side and 82.14 (15.89) on the left side, the normal taken as $100 \%$.

Muscle Cytometry. The average areas of the right tibial cranial muscles were $0.0162 \mathrm{~m}^{2}(0.008)$, after 230 magnification, and $0.0152 \mathrm{~m}^{2}(0.0064)$ for the left tibial cranial muscles (Tables 2 and 3 ). There were no significant differences between right and left muscles.

Electrophysiology. The muscles that showed positive response needed an average of $258.89 \mathrm{mV}$ (92.31) of electric stimulus on the right side and $298.34 \mathrm{mV}$ (139.32) on the left side (Fig. 4).

Statistical Analysis. The statistical analysis (Student's t test) did not show any difference ( $p>0.05)$ between right and left sides for all variables.

\section{DISCUSSION}

In 1992 and 1994, when we first published our results on end-to-side neurorrhaphy with and without epineurium, ${ }^{4,-11}$ a major field of research was opened for the study of the peripheral nerve physiology.

Lundborg ${ }^{5}$ made a significant contribution to the understanding of end-to-side neurorrhaphy by reporting the growth of sensory and motor fibers in the receptor nerve. He also reported that the result in pre-degenerated fibers was better than that in fresh fibers.

Revising our first work ${ }^{4}$ on neurorrhaphy with and without epineurium, we realized that we had similar results for the means of the areas of the tibial cranial muscle fibers, i.e., $1600.64 \mathrm{~m}^{2}$ (533.18) for the window group and $1439.44 \mathrm{~m}^{2}$ (934.5) for the no window group ( $\mathrm{p}=0.6592$ ). However, we did not realize the importance of this finding because we thought it was impossible for there to be no difference between end-to-side neurorrhaphy with and

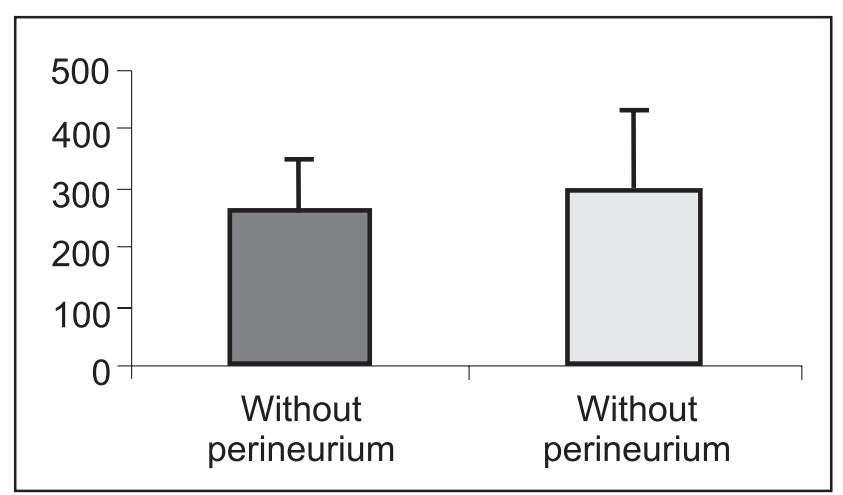

Figure 4 - Electrophysiological test (mV).

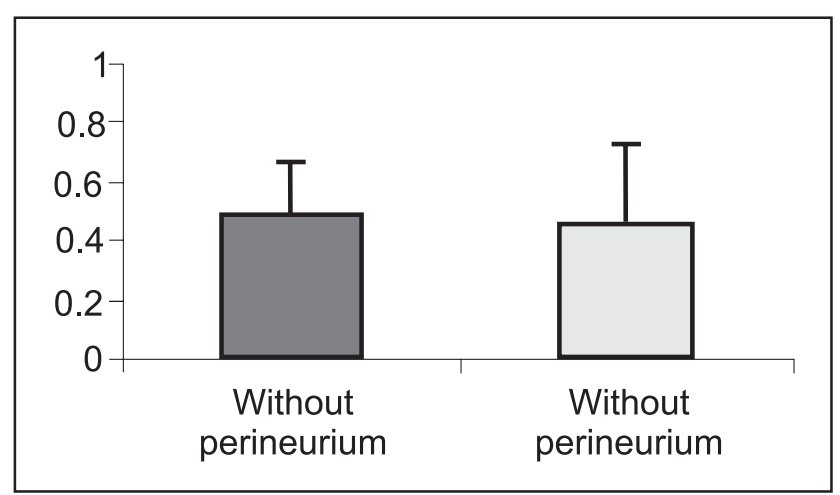

Figure 5 - Weight of the tibial cranial muscles (g).

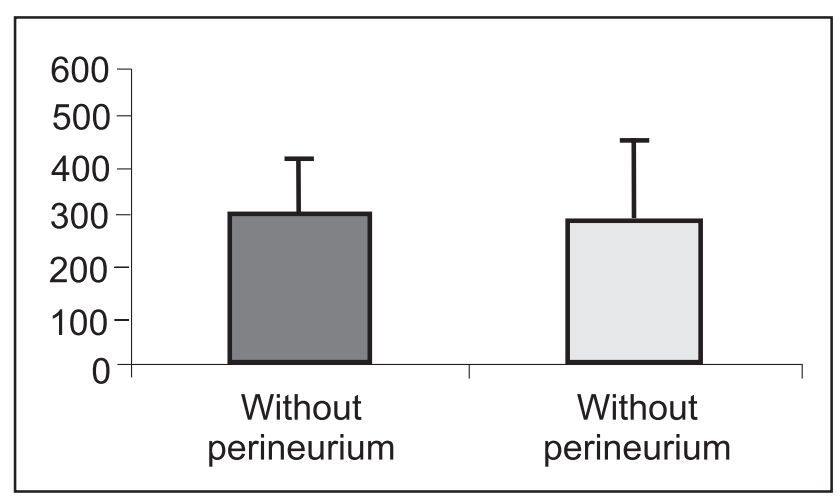

Figure 6 - Distal end of the peroneal nerve (counting).

without epineurium and perineurium. Similarly, Lundborg ${ }^{5}$ did not obtain differences in muscle contractility or supramaximal stimulation of the tibial muscle after 3month reinervation with end-to-side neurorrhaphy for the no window group $(1881 \mathrm{mN})$ and window group $(1818 \mathrm{mN})$. His data supported this concept.

Upon studying end-to-side neurorrhaphy with and without window after a 6-month evaluation of several nerve parameters, we were highly surprised to find no 
significant difference between the two neurorrhaphies. It is important to emphasize that we did not observe differences in the electrophysiological tests, muscle weight, histological evaluation, areas of muscle fibers and counts nerve fiber.

This finding is of utmost importance, as the nonremoval of the perineurium makes the end-to-side neurorrhaphy easier, faster and safer, in addition to diminishing risks of lesion in the donor nerve.

In the first clinical cases of cross-face nerve with end-to-side neurorrhaphy, we did not remove the epineurium for the fear of injuring the normal facial nerve.
The result obtained was similar to that of clinical cases with epineurium removal. ${ }^{9}$

\section{CONCLUSION}

The experimental model showed that both neurorrhaphies (with and without perineural window) did not reveal any difference concerning the morphological and electrophysiological features studied.

Table 1

Results of statistical tests relating to comparisons between the sides for each one of the variables studied.

\begin{tabular}{|c|c|c|c|}
\hline Comparisons & $\begin{array}{l}\text { Number } \\
\text { of pairs }\end{array}$ & $\begin{array}{c}\text { Results of the statistical test } \\
\text { p-value }\end{array}$ & Conclusion \\
\hline TEFD / TEFE(1) & 14 & $t=1.58(p>0.05)$ & $\mathrm{R}=\mathrm{L}$ \\
\hline MTCD weight / MTCE weight & 14 & $t=0.47(p>0.05)$ & $\mathrm{R}=\mathrm{L}$ \\
\hline AMTCD / AMTCE & 14 & $t=0.33(p>0.05)$ & $\mathrm{R}=\mathrm{L}$ \\
\hline MTCD / MTCE (2) & 14 & $t=0.64(p>0.05)$ & $R=L$ \\
\hline TNARS / TNALS ${ }^{(1)}$ & 12 & $t=0.32(p>0.05)$ & TNARS / TNALS \\
\hline TNBRS / TNBLS ${ }^{(1)}$ & 11 & $t=1.09(p>0.05)$ & TNBRS / TNBLS \\
\hline PNRS / PNLS ${ }^{(1)}$ & 14 & $t=0.36(p>0.05)$ & PNRS / PNLS \\
\hline
\end{tabular}

(1) Square transformation variable.

(2) Arc sin transformation variable.

TNARS: segment of the tibial nerve above the neurorraphy, right side

TNALS: segment of the tibial nerve above the neurorraphy, left side

TNBRS: segment of the tibial nerve below the neurorraphy, right side

TNBLS: segment of the tibial nerve below the neurorraphy, left side

PNRS: segment of the peroneal nerve distal to the neurorraphy, right side

PNLS: segment of the peroneal nerve distal to the neurorraphy, left side

Table 2

Means and standard deviations of the studied variables.

\begin{tabular}{lcc}
\hline & $\begin{array}{c}\text { RIGHT SIDE } \\
\text { (without perineurium) }\end{array}$ & $\begin{array}{c}\text { LEFT SIDE } \\
\text { (with perineurium) }\end{array}$ \\
\hline Electrophysiological test $(\mathrm{mV})$ & $258.89(92.31)$ & $298.34(139.32)$ \\
Weight of the tibial cranial muscles $(\mathrm{g})$ & $0.47(0.18)$ & $0.45(0.15)$ \\
Distal end of the peroneal nerve (count) & $310.29(191.34)$ & $287.71(183.60)$ \\
Tibial nerve above the neurorraphy (count) & $939.46(223.51)$ & $959.46(327.48)$ \\
Tibial nerve below the neurorraphy (count) & $935.17(298.65)$ & $755.31(323.26)$ \\
Areas of the tibial cranial muscles (m²) & $0.0162(0.008)$ & $0.0152(0.0064)$ \\
Histological aspect of the tibial cranial muscles & $78.21(20.75)$ & $82.14(15.89)$ \\
(related to normal of $100 \%)$ & & \\
\hline
\end{tabular}


Table 3

Means of the studied variables for all animals.

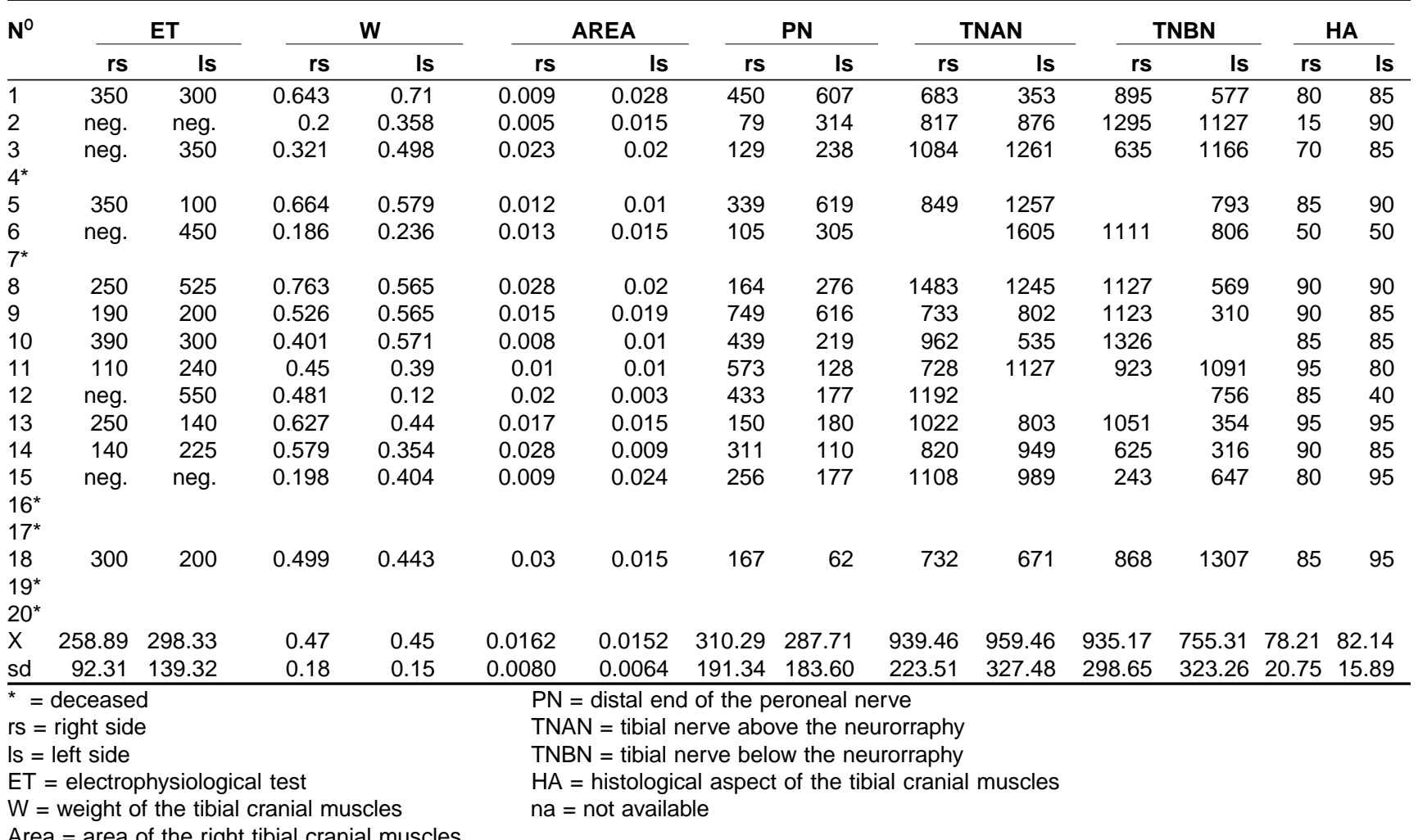

\section{REFERENCES}

1. Ballance CA, Ballance HA, Stewart P. Remarks on the operative treatment of chronic facial palsy of peripheral origin. Br Med J 1903;2:1009-13.

2. Sherren J. Some points in the surgery of the peripheral nerves. Edinburgh: Edinb Med J 1906;20:297-332.

3. Krivolutskaia EG, Tchumassov EI, Matina VN, Meltsova GM, Kirilov AL. Nijiacthka betbeh jihueboro hepba no thny koheu B bok. URSS: Stomachia; 1987.

4. Viterbo F. Neurorrafia látero-terminal, estudo experimental no rato. Botucatu: 1992 (PhD Thesis - Faculdade de Medicina, Universidade Estadual Paulista).

5. Lundborg G, Zhao Q, Kanje M, Danielsen N, Kerns JM. Can sensory and motor collateral sprouting be induced from intact peripheral nerve by end-to-side anastomosis? J Hand Surgery 1994;19B:277-82.

6. Michalany J. In: Técnica histológica em anatomia patológica. São Paulo: Editora Pedagógica e Universitária 1980:128.

7. Box GEP, Hunter WG, Hunter JS. Statistics for experiments. New York: John Wiley \& Sons; 1978:653.

8. Viterbo F, Trindade JC, Hoshino K, Mazzoni Neto A. Latero-terminal neurorraphy without removal of the epineural sheath: experimental study in rats. Rev Paul Med $1992 ; 110(6): 267-75$.
9. Viterbo F. A new method for treatment of facial palsy: the crossface nerve transplantation with end-to-side neurorraphy. Rev Soc Bras Cir Plástica Estética e Reconstrutiva 1993;8(1,2,3):29-38.

10. Viterbo F, Trindade JC, Hoshino K, Mazzoni-Neto A. Two end-to-side neurorraphies and nerve graft with removal of the epineural sheath: experimental study in rats. Brit J Plast Surg 1994;47:75-80.

* This paper was presented as a free-paper during the $64^{\text {th }}$ Annual Scientific Meeting of the American Society of Plastic and Reconstructive Surgery, Plastic Surgery Educational Foundation and American Society of Maxillofacial Surgeons, Montreal, October, 1995

\section{ACKNOWLEDGMENTS}

We wish to thank Dr. Peter C. Johnson very much for the final revision of the text, Dra. Luciana Stip for her valuable collaboration during the surgical procedures, Prof. Dr. Vitalino Dal Pai for the histological analyses, Irene Spago and Carlos Roberto de Carvalho for their valuable collaboration in management of the animals, José Carlos Pedroso de Lima for the laminas feature and Marcos Eduardo Barreiros Aloíse for the drawing of the illustrations. 


\section{ReSUMO}

Objetivos: Comparar a neurorrafia término-lateral com epineuro versus sem epineuro. Desenho: Foram operados 20 ratos. 0 nervo fibular foi seccionado e seu coto distal suturado na face lateral do nervo tibial. Do lado direito nós removemos janela de epineuro e no lado esquerdo o epineuro foi deixado intacto. Depois de seis meses, os 14 animais sobreviventes foram submetidos a testes eletrofisiológicos, sacrificados e os nervos e músculos removidos para exames histológicos. O teste eletrofisiológico foi realizado mediante estímulo elétrico fornecido por um neuro-estimulador (LHM-110) com 2 milisegundos de duração, num modo repetido e $30 \mathrm{~Hz}$. O estímulo foi aumentado progressivamente partindo de zero até atingir 1 volt. Local: Faculdade de Medicina de Botucatu. Resultados: No lado direito, os músculos que tiveram resposta positiva necessitaram uma média de $258,89 \mathrm{mv}( \pm 92,31)$ de estímulo elétrico para apresentar uma resposta e no lado esquerdo uma média de 298,34 $\mathrm{mV}( \pm 139,32)$. O músculo tibial cranial apresentou peso médio para o lado direito de $0,47 \mathrm{~g}( \pm 0,18)$ e para o lado esquerdo de $0,45 \mathrm{~g}( \pm 0,15)$. O coto distal do nervo fibular apresentou uma média 310 fibras nervosas $( \pm 191,34)$ para o lado direito e $287,71( \pm 183,60)$ para o lado esquerdo. O nervo tibial acima da neurorrafia mostrou médias de $939,46( \pm 223,51)$ fibras nervosas para o lado direito e $959,46( \pm 327,48)$ para o lado esquerdo. O nervo tibial abaixo da neurorrafia mostrou médias de $935,17( \pm 298,65)$ fibras nervosas para o lado direito e $755,31( \pm 323,26)$ para o lado esquerdo. As fibras do músculo tibial cranial do lado direito apresentaram uma área média de $0,0162( \pm 0,008) \mathrm{m}^{2}$ depois de 230 vezes de magnificação e $0,0152( \pm 0,0064)$ para as fibras do músculo tibial cranial do lado esquerdo. O aspecto histológico do músculo tibial cranial, tomando-se o normal como $100 \%$ foi de $78,21( \pm 20,75)$ para o lado direito e $82,14( \pm 15,89)$ para o lado esquerdo. A análise estatística (teste " $t$ " de Student) não mostrou diferenças $(p>0,05)$ entre os lados esquerdo e direito para todas as variáveis. Conclusões: Ambas as neurorrafias (com e sem epineuro) não mostraram diferenças relacionadas aos aspectos morfológicos e eletrofisiológicos estudados. 